\title{
The associations of serum S100A9 with the severity and prognosis in patients with community-acquired pneumonia: a prospective cohort study
}

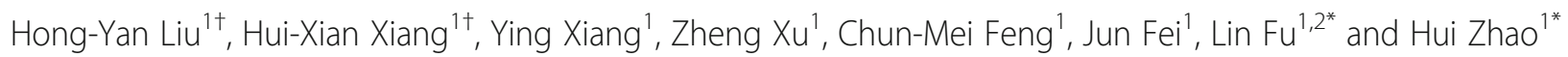

\begin{abstract}
Background: Previous studies found that S100A9 may involve in the pathophysiology of community-acquired pneumonia (CAP). However, the role of S100A9 was unclear in the CAP. The goal was to explore the correlations of serum S100A9 with the severity and prognosis of CAP patients based on a prospective cohort study.

Methods: A total of 220 CAP patients and 110 control subjects were recruited. Demographic and clinical data were collected. Serum S100A9 and inflammatory cytokines were measured.

Results: Serum S100A9 was elevated in CAP patients on admission. Serum S100A9 was gradually elevated parallelly with CAP severity scores. Additionally, inflammatory cytokines were increased and blood routine parameters were changed in CAP patients compared with control subjects. Correlation analysis found that serum S100A9 was positively associated with CAP severity scores, blood routine parameters (WBC, NLR and MON) and inflammatory cytokines. Further, logistic regression analysis demonstrated that there were positive associations between serum S100A9 and CAP severity scores. Besides, the prognosis of CAP was tracked. Serum higher S100A9 on the early stage elevated the death of risk and hospital stay among CAP patients.

Conclusion: Serum S100A9 is positively correlated with the severity of CAP. On admission, serum higher S100A9 elevates the risk of death and hospital stay in CAP patients, suggesting that S100A9 may exert a certain role in the pathophysiology of CAP and regard as a serum diagnostic and managing biomarker for CAP.
\end{abstract}

Keywords: Community-acquired pneumonia, S100A9, Inflammatory cytokines, CAP severity score, Biomarker

\footnotetext{
*Correspondence: fulindev@126.com; zhaohuichenxi@126.com

${ }^{\dagger}$ Hong-Yan Liu and Hui-Xian Xiang contributed equally to this work.

'Respiratory and Critical Care Medicine, Second Affiliated Hospital of Anhui Medical University, Furong Road no 678, Hefei 230601, China

Full list of author information is available at the end of the article
}

(C) The Author(s). 2021 Open Access This article is licensed under a Creative Commons Attribution 4.0 International License, which permits use, sharing, adaptation, distribution and reproduction in any medium or format, as long as you give appropriate credit to the original author(s) and the source, provide a link to the Creative Commons licence, and indicate if changes were made. The images or other third party material in this article are included in the article's Creative Commons licence, unless indicated otherwise in a credit line to the material. If material is not included in the article's Creative Commons licence and your intended use is not permitted by statutory regulation or exceeds the permitted use, you will need to obtain permission directly from the copyright holder. To view a copy of this licence, visit http://creativecommons.org/licenses/by/4.0/ The Creative Commons Public Domain Dedication waiver (http://creativecommons.org/publicdomain/zero/1.0/) applies to the data made available in this article, unless otherwise stated in a credit line to the data. 


\section{Introduction}

Pneumonia is a primary cause of morbidity and mortality all over the world, especially in children and in adults more than 60 years. Every year, 450 million people suffered from pneumonia and 1.3 million cases died of pneumonia [1-3]. Streptococcus pneumoniae (pneumococcus) is one of the commonest bacterial pathogensinducing community-acquired pneumonia (CAP), which results in substantial health and economic burden $[4,5]$. Previous studies found that CAP accounts for more than 60,000 deaths, 1.2 million hospitalizations, 2.3 million emergency department visits and $\$ 10$ billion in hospital costs in United States yearly [6, 7]. In order to reduce the mortality and prevent CAP clinical deterioration, it is very necessary to diagnose the disease and evaluate the severity of CAP at the time of disease onset. Nevertheless, early recognition and evaluation the risk of CAP are difficult. The sensitivity and specificity of different biochemical markers and laboratory testing are variable and largely limited [8]. Therefore, additional new biomarkers are essentially needed to evaluate the severity and simplify the diagnosis progress.

S100A9, a small $\mathrm{Ca}^{2+}$ binding protein recognized as an alarmin, is released by stressed cells: an endogenous danger signal, which promotes and exacerbates the inflammatory response [9]. S100A9 forms a complex with S100A8 (S100A8/S100A9 heterodimer) to exhibit different inflammatory effects via toll-like receptor 4 (TLR4) $[10,11]$, scavenger receptor CD36 [12] and receptor of advanced glycated end products (RAGE) [13]. Released of S100A9 activates several signaling pathways and exerts important functions in a great deal of cellular processes [10, 14-16]. The previous studies found that S1009A9 is elevated in several diseases, such as neutrophilic inflammation in asthma, insulin deficiency, atopic dermatitis and Parkinson's disease [17-20]. In addition, our previous study found that S100A8/S100A9 is increased in COPD patients and positively associated with inflammatory cytokines [21]. Therefore, these results indicate that S100A9 may be used as a biomarker for the diagnosis of disease.

An early study revealed that S100A9 was increased in the lung of patients with non-small cell carcinoma [22]. Perinatal inflammation exposure modified lung morphogenesis, elevated the level of S100A9 in fetal mice [23]. TLR4/RAGE signaling was activated and S100A9 was increased under endotoxemia-induced pulmonary inflammation [24]. These data indicated that S100A9 may play an important role in the pulmonary diseases. However, the role of S100A9 protein remains unknown in CAP patients. Therefore, the main purpose of current research was to analyze the correlations of serum S100A9 with the severity and prognosis in CAP patients based on a prospective cohort study.

\section{Methods}

\section{Subjects}

This prospective study was conducted in the Second Affiliated Hospital of Anhui Medical University between May 1, 2018 to June 30, 2020. Altogether, 220 patients with CAP were recruited in the Department of Respiratory and Critical Care Medicine. Demographic and clinical data were collected from Electronic Medical Record System on admission. For CAP patients, the inclusion criteria met the following criteria of CAP [25]; more than 18 years old; signed written inform consents. The exclusion criteria included: severely immunocompromised; pregnant women; patients with other pulmonary diseases, such as serious complications, COPD, lung cancer and asthma; hospital stay was less than 5 days. Healthily control subjects were enrolled from the physical examination center. In the beginning, 260 patients with CAP were enrolled. Two hundred and forty-six cased agreed to perform follow-up research. Twelve patients with incomplete information and 14 patients who were lost were excluded. Finally, 220 patients with CAP involved in this research (Fig. 1). The severity of pneumonia was assessed using CAP severity scores, including pneumonia severity index (PSI), CURB-65 score, CRB-65 score, CURXO score and SMART-COP score. This study was approved by the Ethics Committee in Second Affiliated Hospital of Anhui Medical University. All subjects gave advanced written and oral agreement of their inclusion in this study.

\section{Enzyme-linked immunosorbent assay (ELISA)}

Whole blood was collected at six o'clock in the morning and centrifuged on basis of our previous study [26, 27]. Serum was collected and inflammatory cytokines were measured using enzyme-linked immunosorbent assay (ELISA). Human inflammatory cytokines ELISA kits were obtained from Cusabio, Wuhan, China (https:// www.cusabio.com/). Human S100A9 ELISA kits were purchased from Wuhan Colorful Gene Biological Technology Co. Serum S100A9 and inflammatory cytokines were measured according to standard methods [28, 29].

\section{Statistical analysis}

All analysis was conducted with GraphPad Prism 5.0 and SPSS 19.0 software. Clinical features, cytokines and CAP severity scores were compared using Student's $t$ tests, Chi-square tests or Manne-Whitney U tests among different groups. Continuous variables were exhibited median and interquartile range (IQR). Association analysis were performed using linear regression and logistic regression. In order to control confounding factors, age and sex were adjusted. Finally, the multivariate logistic regression analysis was carried out. A two-sided $P$-value of less that 0.05 was regarded as statistically significant. 


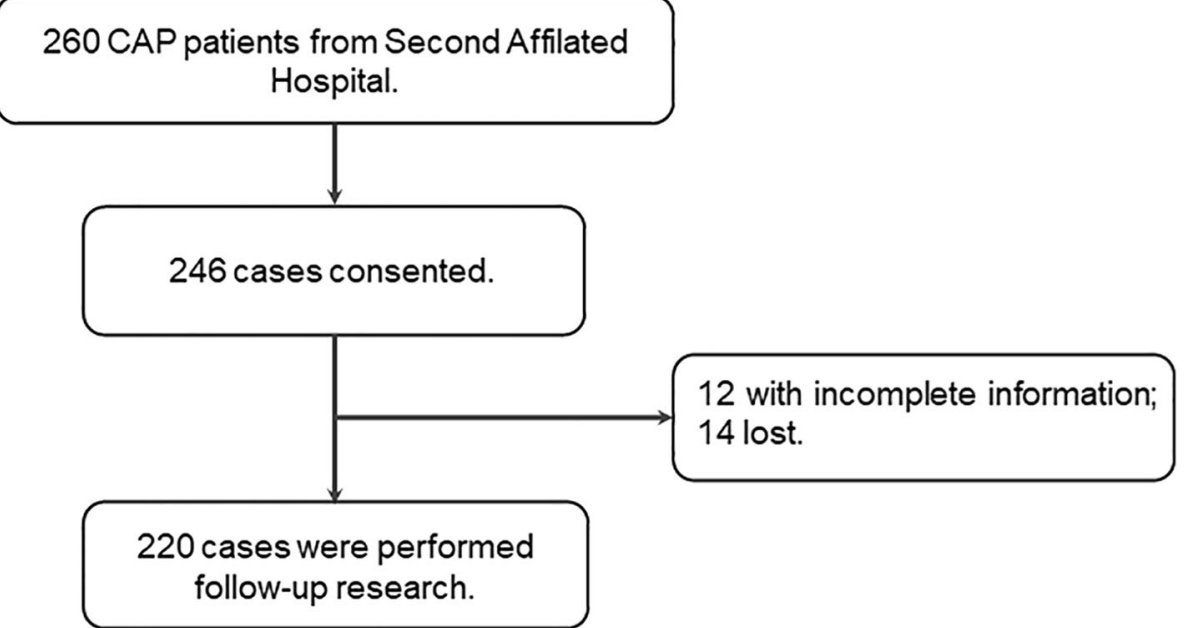

Fig. 1 Flow diagram of recruitment and follow-up research in this cohort study

\section{Results}

\section{Demographic and clinical data}

In total, 220 CAP patients and 110 healthily control subjects were recruited and analyzed in the present study. As shown in Table 1, there was no notable different of age, gender and BMI between CAP patients and control cases. Routine blood test was detected between two groups. We found that white blood cell (WBC) and neutrophil were increased, lymphocyte was decreased in CAP patients. The ratios of platelet-lymphocyte (PLR), monocyte-lymphocyte (MON) and neutrophillymphocyte (NLR) were increased in patients with CAP (Table 1). Moreover, liver function and renal function were detected among all cases. As shown in Table 1, except for uric acid, no difference of liver function and renal function was observed in two groups. In addition, inflammatory cytokines were measured. The levels of TNF- $\alpha$, IL- $1 \beta$, IL- 6 and CRP were elevated in CAP patients. Meanwhile, the severity of pneumonia was assessed with CAP severity scores. Among 220 patients with CAP, the median of PSI, CURB-65, CRB-65 and SMART-COP score was 2.0, 1.0, 94.0 and 2.0, respectively. Additionally, there was $92(41.8 \%)$ severe patients in CAP group (CURXO score) (Table 1).

\section{The levels of serum S100A9 in control subjects and CAP patients}

Serum S100A9 was measured between CAP patients and control subjects. As shown in Fig. 2a, serum S100A9 was increased in CAP patients compared with control subjects. Additionally, serum S100A9 was analyzed among different grades of CAP patients. As shown in Fig. 2b, serum S100A9 was higher in $\geq 3$ score grade than in other grades based on CRB-65 score. According to
SMART-COP score, serum S100A9 was higher in 7 8 score than in other grades (Fig. 2c). Besides, we found that serum S100A9 was higher in severe CAP patients than those in mild CAP patients (CURXO score) (Fig. 2d). What's more, serum S100A9 was lowest in $0 \sim 1$ score and was highest in $3 \sim 5$ score on the basis of CURB-65 score (Fig. 2e). Furthermore, the level of serum S100A9 was increased in the grade of III than those in the grades of II and I based on PSI score. Serum S100A9 was highest in the grade of IV (Fig. 2f).

\section{Correlations of S100A9 with disease severity, blood routine parameters and inflammatory cytokines among CAP patients}

The correlations between S100A9 and CAP severity scores were analyzed among CAP patients. We found that serum S100A9 was positively correlated with CURB-65 $(r=0.501, P=0.001)$, CRB-65 $(r=0.488, P=$ $0.001)$, PSI $(r=0.567, P<0.001)$, CURXO $(r=0.502, P=$ $0.003)$ and SMART-COP $(r=0.475, P<0.001)$ (Table 2$)$. Additionally, the correlations between S100A9 and blood routine parameters were explored. As shown in Table 2, serum S100A9 was positively correlated with WBC $(r=0.297, P=0.003)$, NLR $(r=0.274, P=0.006)$ and MON $(r=0.277, P=0.012)$. Meanwhile, we also observed the correlations between serum S100A9 and inflammatory cytokines. We found that there was positive correlations between serum S100A9 with TNF- $\alpha$ ( $r=$ $0.248, P=0.001)$, IL-1 $\beta(r=0.273, P<0.001)$ and CRP $(r=0.345, P=0.002)$. Finally, associations between serum S100A9 and CAP severity scores were further analyzed using univariate and multivariate logistic regression. The univariate logistic regression indicated that serum 
Table 1 Demographic and biochemical characteristics between CAP patients and No-CAP patients

\begin{tabular}{|c|c|c|c|}
\hline Variables & CAP $(n=220)$ & No-CAP $(n=110)$ & $P$ \\
\hline Age (years) & $67.0(55.0,80.0)$ & $64.0(52.0,75.0)$ & 0.452 \\
\hline Male, n (\%) & $124(56.5)$ & $61(55.0)$ & 0.121 \\
\hline BMI & $23.0(20.2,25.1)$ & $22.3(19.8,24.9)$ & 0.098 \\
\hline WBC $\left(10^{9} / \mathrm{L}\right)$ & $6.80(5.04,9.35)$ & $5.66(4.71,6.81)$ & $<0.05$ \\
\hline Neutrophil $\left(10^{9} / \mathrm{L}\right)$ & $5.01(3.13,7.51)$ & $3.10(2.41,3.95)$ & $<0.05$ \\
\hline Lymphocyte $\left(10^{9} / \mathrm{L}\right)$ & $1.25(0.86,1.91)$ & $2.15(1.86,2.51)$ & $<0.05$ \\
\hline Eosinophil $\left(10^{9} / \mathrm{L}\right)$ & $0.07(0.02,0.17)$ & $0.11(0.04,0.16)$ & 0.061 \\
\hline Monocytes $\left(10^{9} / \mathrm{L}\right)$ & $0.45(0.32,0.61)$ & $0.35(0.31,0.43)$ & 0.060 \\
\hline Basophil $\left(10^{9} / \mathrm{L}\right)$ & $0.02(0.01,0.03)$ & $0.02(0.01,0.03)$ & 0.078 \\
\hline NLR & $3.88(2.02,8.93)$ & $1.50(1.31,2.35)$ & $<0.01$ \\
\hline MON & $0.32(0.20,0.57)$ & $0.19(0.14,0.23)$ & $<0.05$ \\
\hline PLR & $181.4(117.2,338.4)$ & $109.2(89.6,136.8)$ & $<0.05$ \\
\hline $\operatorname{ALT}(\mathrm{U} / \mathrm{L})$ & $19.0(12.0,38.3)$ & $17.9(11.2,23.3)$ & 0.121 \\
\hline AST (U/L) & $24.0(18.0,36.0)$ & $23.1(15.1,25.1)$ & 0.082 \\
\hline Total bilirubin (umol/L) & $10.3(8.2,15.1)$ & $14.6(12.6,19.3)$ & 0.065 \\
\hline Direct bilirubin ( $\mu \mathrm{mol} / \mathrm{L})$ & $2.6(1.8,3.6)$ & $2.5(2.2,3.4)$ & 0.187 \\
\hline Total protein (g/L) & $64.6(59.2,67.9)$ & $75.6(66.2,81.3)$ & 0.241 \\
\hline Albumin (g/L) & $33.0(28.2,38.2)$ & $44.5(40.2,49.6)$ & 0.111 \\
\hline Globulin (g/L) & $29.9(25.5,35.6)$ & $26.8(20.1,34.5)$ & 0.101 \\
\hline Urea nitrogen (mmol/L) & $5.21(4.03,7.11)$ & $4.56(3.61,5.15)$ & 0.387 \\
\hline Creatinine $(\mu \mathrm{mol} / \mathrm{L})$ & $58.0(47.0,75.5)$ & $60.3(46.5,78.0)$ & 0.412 \\
\hline Uric acid ( $\mu \mathrm{mol} / \mathrm{L})$ & $276.0(199.0,333.0)$ & $395.3(260.5,462.3)$ & $<0.05$ \\
\hline TNF-a (pg/mL) & $560.9(291.8,1121.8)$ & $62.3(38.6,100.3)$ & $<0.01$ \\
\hline IL-6 (pg/mL) & $70.6(43.4,94.3)$ & $28.9(19.8,59.8)$ & $<0.01$ \\
\hline $\mathrm{IL}-1 \beta(\mathrm{pg} / \mathrm{mL})$ & $361.6(197.2,581.2)$ & $60.2(20.3,85.5)$ & $<0.01$ \\
\hline CRP (mg/L) & $43.3(4.7,98.2)$ & $8.9(2.2,30.1)$ & $<0.01$ \\
\hline CURB-65 & $2.0(0,3.0)$ & N.A & N.A \\
\hline CRB-65 & $1.0(0,2.0)$ & N.A & N.A \\
\hline PSI & $94.0(59.0,130.0)$ & N.A & N.A \\
\hline CURXO [Severe, n (\%)] & $92(41.8)$ & N.A & N.A \\
\hline SMART-COP & $2.0(0,5.0)$ & N.A & N.A \\
\hline
\end{tabular}

S100A9 was positively correlated with CURB-65 (OR = 1.358; 95\% CI: 1.121, 1.652), CRB-65 (OR = 1.223; 95\% CI: $1.025,1.562)$, PSI (OR $=1.325 ; 95 \% \mathrm{CI}: 1.056,1.762)$, SMART-COP $(\mathrm{OR}=1.262 ; 95 \% \mathrm{CI}: 1.050,1.462)$ and CURXO (OR $=1.451$; 95\% CI: 1.215, 1.864) (Table 3). Confounding factors were controlled and adjusted and the multivariate logistic regression was further performed. These results indicated that serum S100A9 was positively associated with PSI (OR $=1.225 ; 95 \% \mathrm{CI}$ : $1.035,1.562)$, SMART-COP $(\mathrm{OR}=1.212$; $95 \% \mathrm{CI}: 1.065$, $1.615)$ and CURXO (OR $=1.116 ; 95 \% \mathrm{CI}: 1.011,1.365)$ (Table 3).
The association between serum S100A9 and the prognosis in CAP patients

The level of serum S100A9 were compared between alive patients and dead cases. Eighteen CAP patients were died during hospitalization. As shown in Fig. 3a, serum S100A9 was increased in dead patients than these in alive CAP patients. Moreover, the levels of serum S100A9 was higher in $>14$ days than these in $<8$ days and $8 \sim 14$ days (Fig. 3b). Besides, the associations between serum S100A9 and the prognosis of CAP patients were analyzed using logistic regression. The univariate logistic regression revealed that serum S100A9 was positively 

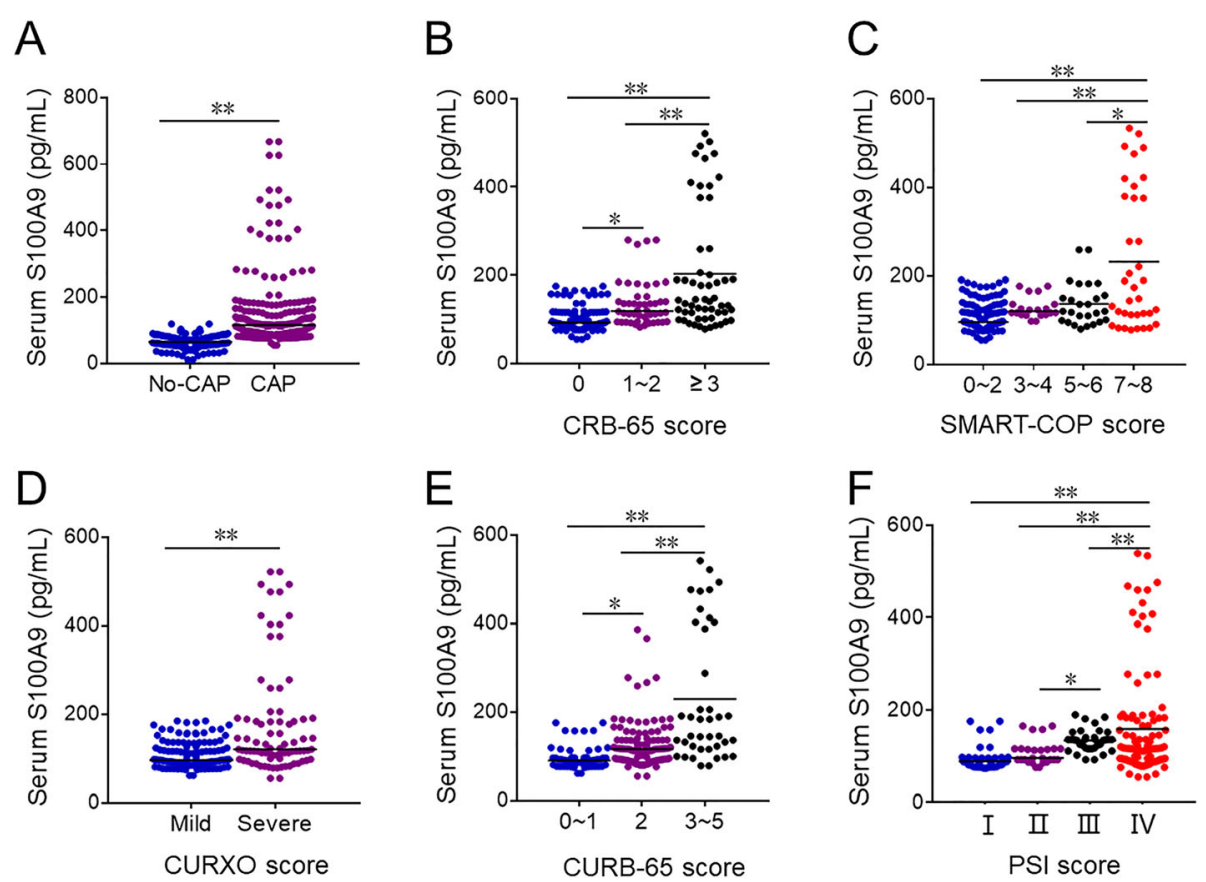

Fig. 2 The levels of serum 8-iso-PGF2a in control subjects and CAP patients. a-f Serum S100A9 was detected with ELISA. a The level of serum S100A9 in CAP patients and No-CAP cases. $\mathbf{b}$ The level of serum S100A9 in different grades of CRB-65 score in CAP patients. $\mathbf{c}$ The level of serum S100A9 in different grades of SMART-COP score in CAP patients. $\mathbf{d}$ The level of serum S100A9 in different grades of CURXO score in patients with CAP. e The level of serum S100A9 in different grades of SMART-COP score in CAP patients. $\mathbf{f}$ The level of serum S100A9 in different grades of PSI score in CAP patients. All data were expressed as mean \pm SEM. ${ }^{*} P<0.05,{ }^{* *} P<0.01$

associated with hospital stay $(\mathrm{OR}=1.159 ; 95 \% \mathrm{CI}: 1.062$, $1.321)$ and the risk of death $(\mathrm{OR}=1.112 ; 95 \% \mathrm{CI}: 1.010$, 1.336) (Table 4). In order to control confounding factors, the multivariate logistic regression was continued to performing. The results found that serum S100A9 was positively associated with the risk of death $(\mathrm{OR}=1.137 ; 95 \%$ CI: 1.023, 1.312).

Table 2 Correlations of serum S100A9 with disease severity, blood routine examination and inflammatory cytokines

\begin{tabular}{|c|c|c|c|c|c|}
\hline \multicolumn{6}{|c|}{ Disease severity } \\
\hline Variables & CURB-65 & CRB-65 & PSI & CURXO & SMART-COP \\
\hline r & 0.501 & 0.488 & 0.567 & 0.502 & 0.475 \\
\hline$P$ & 0.001 & 0.001 & $<0.001$ & 0.003 & $<0.001$ \\
\hline \multicolumn{6}{|c|}{ Blood routine examination } \\
\hline Variables & WBC & Neutrophil & Lymphocyte & NLR & MON PLR \\
\hline$r$ & 0.297 & 0.135 & -0.051 & 0.274 & $0.277 \quad 0.193$ \\
\hline$P$ & 0.003 & 0.098 & 0.621 & 0.006 & 0.0120 .081 \\
\hline \multicolumn{6}{|c|}{ Inflammatory cytokines } \\
\hline Variables & TNF-a & $\| L-1 \beta$ & CRP & $\mathrm{IL}-6$ & \\
\hline$r$ & 0.248 & 0.273 & 0.345 & 0.057 & \\
\hline P & 0.001 & $<0.001$ & 0.002 & 0.688 & \\
\hline
\end{tabular}

The predictive capacity of serum S100A9 for CAP

The predictive capacity of serum S1009A was analyzed using receiver operating characteristic area under the curve (AUC). As shown in Fig. 4a, the AUC of S100A9 for CAP was 0.788 (95\% CI: 0.699, 0.878). The sensitivity and specificity of S100A9 in the prediction of CAP were 73.5 and $82.5 \%$. Furthermore, the predictive capacity of serum S1009A for severity was analyzed among CAP patients. We found that the AUCs for different biomarkers were as follows: CURB-65, 0.893 (95\% CI: 0.832, 0.954); CRB-65, 0.886 (95\% CI: 0.823, 0.950); PSI, 0.919 (95\% CI: 0.891, 0.987); SMART-COP, 0.916 (95\% CI: 0.932, 0.998); CURXO, 0.880 (0.810, 0.951); S100A9, 0.832 (95\% CI: 0.715, 0.943) (Fig. 4b). The optimal cut-off value of serum S100A9 level was $213.6 \mathrm{pg} / \mathrm{mL}$ with $76.0 \%$ sensitivity and $82.0 \%$ specificity.

\section{Discussion}

This study mainly analyzed the associations between serum S100A9 with the severity and the prognosis in CAP patients based on a prospective cohort study. The present study mainly found that: (1) Serum S100A9 was elevated in CAP patients; (2) Serum S100A9 on admission was positively associated with CAP severity scores; (3) Serum S100A9 on admission was positively 
Table 3 Associations between serum S100A9 and CAP severity scores among CAP patients

\begin{tabular}{|c|c|c|c|c|}
\hline Variables & Univariate, OR(95\% Cl) & $P$ & Multivariate, OR(95\% Cl) ${ }^{\mathrm{a}}$ & $P$ \\
\hline CURB-65 & $1.358(1.121,1.652)$ & 0.003 & $0.981(0.955,1.007)$ & 0.149 \\
\hline CRB-65 & $1.223(1.025,1.562)$ & 0.005 & $0.986(0.970,1.003)$ & 0.112 \\
\hline PSI & $1.325(1.056,1.762)$ & 0.001 & $1.225(1.035,1.562)$ & 0.041 \\
\hline SMART-COP & $1.262(1.050,1.462)$ & 0.001 & $1.212(1.065,1.615)$ & 0.030 \\
\hline CURXO & $1.451(1.215,1.864)$ & 0.004 & $1.116(1.011,1.365)$ & 0.033 \\
\hline
\end{tabular}

${ }^{\mathrm{a}}$ Adjusted for age and sex

associated with inflammatory cytokines; (4) Serum higher S100A9 on admission elevates mortality and hospital stay in CAP patients.

Earlier studies found that S100A9 is elevated in several diseases, such as neutrophilic inflammation in asthma, insulin deficiency, atopic dermatitis and Parkinson's disease [17-20]. Moreover, a report from our laboratory indicated S100A8/S100A9 is increased in COPD patients and positively associated with inflammatory cytokines [21]. However, the role of S100A9 in CAP and the associations between serum S100A9 and the severity of CAP were unknown. In the present study, we found that serum S100A9 was elevated in CAP patients. Moreover, serum S100A9 was gradually increased in parallel with the severity of CAP. Further logistic regression analysis found that serum S100A9 was positively associated with the severity of CAP. These results reveal that S100A9 may take part in the pathophysiology process of CAP.

Previous research found that inflammation is increased in CAP patients [30]. In this study, we also found that several inflammatory cytokines were elevated in CAP patients. Not only that, serum S100A9 was positively associated with inflammatory cytokines in CAP patients. Besides, some earlier studies revealed that blood routine indices were changed in CAP patients compared with control subjects [31, 32]. This research found that WBC and neutrophil were increased, lymphocyte was reduced in CAP patients. The ratios of PLR, MON and NLR were increased in patients with CAP. Further correlation analysis demonstrated that serum S100A9 was positively correlated with WBC, NLR and MON. These results suggested that the level of serum S100A9 may reflect the pathophysiologic conditions for CAP in a certain extent.

The association between serum S100A9 and the severity of CAP has been explored. However, the influence of S100A9 on the prognosis of CAP patients remains unclear. The present study analyzed the effect of S100A9 on the death of risk among CAP patients. These results found that the level of serum S100A9 was increased in dead patients on admission. Univariate and multivariate logistic regression analysis verified that serum higher S100A9 on admission elevated the risk of death of CAP patients. Moreover, we found that the higher serum S100A9 was, the longer hospital stay was. Univariate
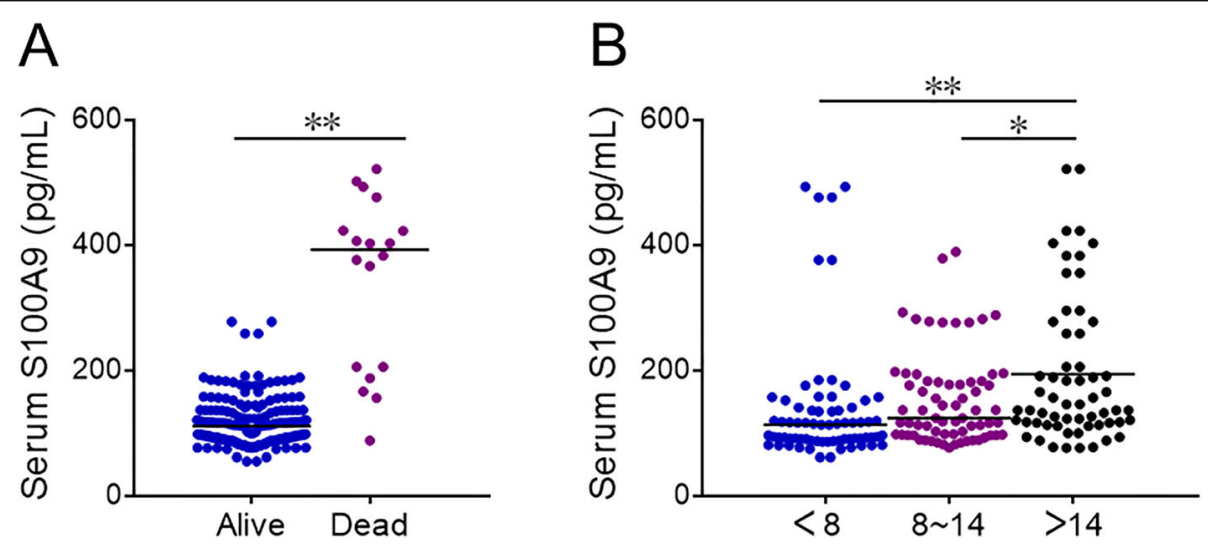

Fig. 3 The levels of serum S100A9 in alive and dead CAP patients. a and b Serum S100A9 was detected with ELISA. a The level of serum S100A9 in alive and dead CAP patients. $\mathbf{b}$ The level of serum S100A9 in different hospital stay of alive patients. All data were expressed as mean \pm SEM. ${ }^{*} P<0.05,{ }^{*} P<0.01$ 
Table 4 Association between serum S100A9 and prognosis among CAP patients

\begin{tabular}{lllll}
\hline Variables & Univariate, OR (95\% Cl) & $\boldsymbol{P}$ & Multivariate, OR (95\% Cl) $^{\mathbf{a}}$ & \multicolumn{1}{c}{} \\
\hline Death & $1.112(1.010,1.336)$ & 0.001 & $1.137(1.023,1.312)$ & 0.012 \\
Hospital stay & $1.159(1.062,1.321)$ & 0.001 & $1.001(0.986,1.016)$ & 0.885
\end{tabular}

${ }^{\mathrm{a}}$ Adjusted for age and sex

logistic regression analysis suggested that serum S100A9 on admission was positively related with hospital stay in CAP patients. These results proved that serum higher S100A9 on the early stage always indicated a serious prognosis for CAP patients. In order to confirm the predictive capacity, the ROC curve was analyzed. The AUC value of serum S100A9 for CAP was 0.788 (95\% CI: 0.699, 0.878). In addition, the predictive quality of serum S100A9 and CAP severity scores for severity were similar. Besides, the predictive power of serum S100A9 was superior to several known biomarkers though literature review $[31,33]$. Hence, these results provide additional evidence that serum S100A9 can be used as a better diagnostic biomarker for CAP.

This study mainly explored the relationships between serum S100A9 on the early stage with the severity and prognosis in CAP patients. However, there are several potential flaws in this study. Firstly, all CAP patients and control subjects were recruited from one hospital rather than from multicenter in China. The sample size was relatively small. So, the larger sample size and multicenter studies are needed in the future clinical research. Secondly, this was only a clinical epidemiology research, the mechanism of
S100A9 elevation in CAP patients is needed to further clarify with in vitro experiments. Thirdly, S100A9 was only detected in serum, the local levels of S100A9 in sputum, lungs and bronchoalveolar lavage fluid are unknown in CAP patients. Fourthly, S100A9 was only detected in CAP patients. The levels and changes of S100A9 in patients with other pneumonias are unclear. The difference of S100A9 will be compared between CAP patients and other pneumonias' patients in the next work.

\section{Conclusion}

In summary, this study mainly analyzed the associations between serum S100A9 on admission with the severity and prognosis among CAP patients based on a prospective cohort study. Our results reveal that serum S100A9 is elevated in CAP patients on admission. In addition, serum S100A9 is positively associated with the severity of CAP on admission. We provide evidence that serum higher S100A9 at the early stage elevates the risk of death and hospital stay of CAP patients. Therefore, S100A9 may be regarded as a diagnostic biomarker and useful for the clinical management of CAP in the future clinical practice.

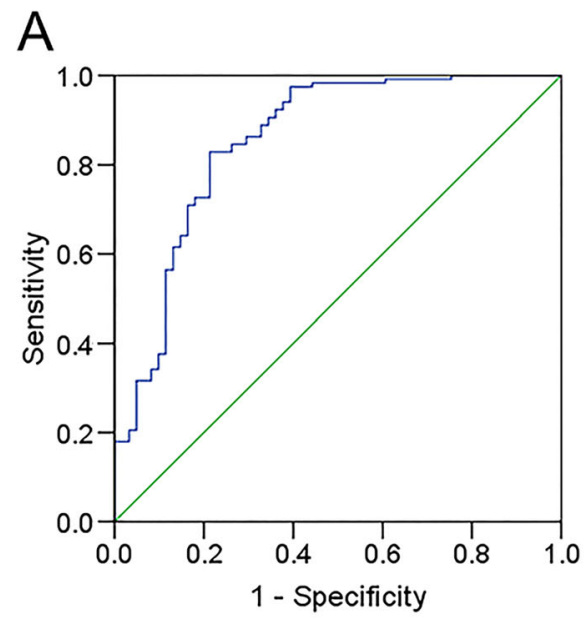

B

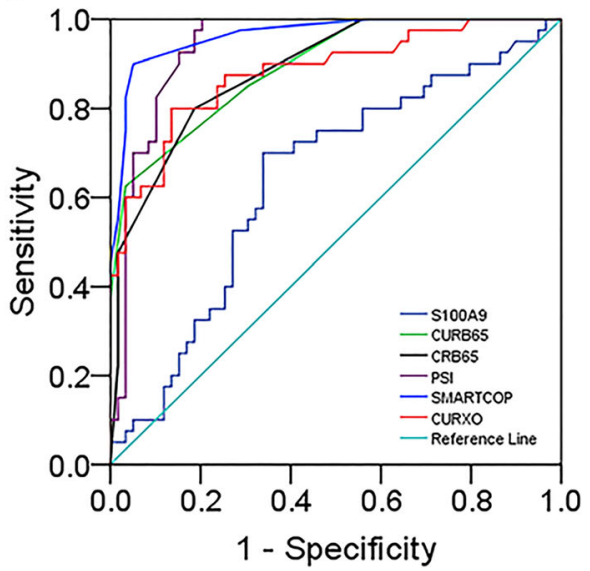

Fig. 4 Receiver operating characteristic curves of different predictive biomarkers for CAP. a ROC curve was used to assess the diagnostic capacity of serum S100A9 for CAP. b ROC curve was used to assess the diagnostic value of different biomarkers (S100A9, CRB-65, CURB-65, CURXO, SMAR T-COP and PSI) for the severity of CAP 


\section{Abbreviations}

CAP: Community-acquired pneumonia; WBC: White blood cell; NLR: Neutrophil-lymphocyte ratio; MON: Monocyte-lymphocyte ratio; PLR: Platelet-lymphocyte ratio; TNF-a: Tumor necrosis factor a; IL$1 \beta$ : Interleukin-1ß; CRP: C-reactive protein

\section{Acknowledgments}

We thank all patients and their families involved in this research. We also thank all members of Respiratory and Critical Care Medicine in the Second Affiliated Hospital of Anhui Medical University.

\section{Authors' contributions}

$\mathrm{HZ}$ and LF contributed to the design of the study, statistical analyses and drafting the manuscript. HYL, HXX, YX, ZX, CMF, JF and ZL contributed to samples collection, data interpretation and helping with drafting the manuscript. HYL and HXX contributed to recruiting patients and obtaining their written informed consent. All authors participated in reviewing the manuscript and revising it critically before submission. All authors have read carefully and approved the final manuscript.

\section{Funding}

This study was supported by National Natural Science Foundation Incubation Program of the Second Affiliated Hospital of Anhui Medical University (grant number: 2019GQFY06 and 2020GQFY05).

\section{Availability of data and materials}

The datasets used and analyzed during the current study are available from the corresponding author on reasonable request.

\section{Declarations}

\section{Ethics approval and consent to participate}

This study was supported by the Ethics Committee of Anhui Medical University and reached the principles expressed in the Declaration of Helsinki. Oral agreement or consent form was gained from patients or patients' next of kin.

\section{Consent for publication}

Not applicable.

\section{Competing interests}

All authors have declared that no competing interest exists.

\section{Author details}

${ }^{1}$ Respiratory and Critical Care Medicine, Second Affiliated Hospital of Anhui Medical University, Furong Road no 678, Hefei 230601, China. ²Department of Toxicology, Anhui Medical University, Hefei 230032, China.

Received: 1 November 2020 Accepted: 28 March 2021

Published online: 07 April 2021

\section{References}

1. Wunderink RG, Waterer G. Advances in the causes and management of community acquired pneumonia in adults. BMJ. 2017;358:j2471.

2. Lanks CW, Musani Al, Hsia DW. Community-acquired pneumonia and hospital-acquired pneumonia. Med Clin North Am. 2019;103(3):487-501. https://doi.org/10.1016/j.mcna.2018.12.008

3. Yu Y, Fei A. Atypical pathogen infection in community-acquired pneumonia. Biosci Trends. 2016:10(1):7-13. https://doi.org/10.5582/bst.2016.01021.

4. Marrie TJ, Huang JQ. Epidemiology of community-acquired pneumonia in Edmonton, Alberta: an emergency department-based study. Can Respir J. 2005;12(3):139-42. https://doi.org/10.1155/2005/672501.

5. Welte T, Torres A, Nathwani D. Clinical and economic burden of community-acquired pneumonia among adults in Europe. Thorax. 2012 67(1):71-9. https://doi.org/10.1136/thx.2009.129502

6. Self WH, Grijalva CG, Zhu Y, McNaughton CD, Barrett TW, Collins SP, et al. Rates of emergency department visits due to pneumonia in the United States, July 2006-June 2009. Acad Emerg Med. 2013;20(9):957-60. https:// doi.org/10.1111/acem.12203.

7. Kung HC, Hoyert DL, Xu J, Murphy SL. Deaths: final data for 2005. Natl Vita Stat Rep. 2008;56(10):1-120.
8. Dremsizov T, Clermont G, Kellum JA, Kalassian KG, Fine MJ, Angus DC Severe sepsis in community-acquired pneumonia: when does it happen and do systemic inflammatory response syndrome criteria help predict course? Chest. 2006;129(4):968-78. https://doi.org/10.1378/chest.129.4.968.

9. Pansieri J, Ostojić L, lashchishyn IA, Magzoub M, Wallin C, Wärmländer SKTS, et al. Pro-inflammatory S100A9 protein aggregation promoted by NCAM1 peptide constructs. ACS Chem Biol. 2019;14(7):1410-7. https://doi.org/10.1 021/acschembio.9b00394.

10. Loser K, Vogl T, Voskort M, Lueken A, Kupas V, Nacken W, et al. The toll-like receptor 4 ligands Mrp8 and Mrp14 are crucial in the development of autoreactive CD8+ T cells. Nat Med. 2010;16(6):713-7. https://doi.org/10.103 $8 / \mathrm{nm} .2150$

11. Vogl T, Tenbrock K, Ludwig S, Leukert N, Ehrhardt C, van Zoelen MA, et al. Mrp8 and Mrp14 are endogenous activators of toll-like receptor 4, promoting lethal, endotoxin-induced shock. Nat Med. 2007;13(9):1042-9. https://doi.org/10.1038/nm1638.

12. Kawano $T$, Shimamura M, Nakagami $H$, Iso T, Koriyama $H$, Takeda $S$, et al. Therapeutic vaccine against S100A9 (S100 calcium-binding protein A9) inhibits thrombosis without increasing the risk of bleeding in ischemic stroke in mice. Hypertension. 2018;72(6):1355-64. https://doi.org/10.1161/ HYPERTENSIONAHA.118.11316.

13. Eggers K, Sikora K, Lorenz M, Taubert T, Moobed M, Baumann G, et al. RAGE-dependent regulation of calcium-binding proteins S100A8 and S100A9 in human THP-1. Exp Clin Endocrinol Diabetes. 2011;119(6):353-7. https://doi.org/10.1055/s-0030-1268426.

14. Koy M, Hambruch N, Hussen J, Pfarrer C, Seyfert HM, Schuberth HJ. Recombinant bovine S100A8 and A9 enhance IL-1 $\beta$ secretion of interferongamma primed monocytes. Vet Immunol Immunopathol. 2013;155(3):16270. https://doi.org/10.1016/j.vetimm.2013.07.002

15. Kerkhoff C, Sorg C, Tandon NN, Nacken W. Interaction of S100A8/S100A9arachidonic acid complexes with the scavenger receptor CD36 may facilitate fatty acid uptake by endothelial cells. Biochemistry. 2001:40(1):2418. https://doi.org/10.1021/bi001791k.

16. Boyd JH, Kan B, Roberts H, Wang Y, Walley KR. S100A8 and S100A9 mediate endotoxin-induced cardiomyocyte dysfunction via the receptor for advanced glycation end products. Circ Res. 2008:102(10):1239-46. https:// doi.org/10.1161/CIRCRESAHA.107.167544.

17. Ramadori G, Ljubicic S, Ricci S, Mikropoulou D, Brenachot X, Veyrat-Durebex C, et al. S100A9 extends lifespan in insulin deficiency. Nat Commun. 2019; 10(1):3545. https://doi.org/10.1038/s41467-019-11498-x.

18. Lee TH, Chang HS, Bae DJ, Song HJ, Kim MS, Park JS, et al. Role of S100A9 in the development of neutrophilic inflammation in asthmatics and in a murine model. Clin Immunol. 2017:183:158-66. https://doi.org/10.1016/j. clim.2017.08.013.

19. Horvath I, lashchishyn IA, Moskalenko RA, Wang C, Wärmländer SKTS, Wallin C, et al. Co-aggregation of pro-inflammatory S100A9 with a-synuclein in Parkinson's disease: ex vivo and in vitro studies. J Neuroinflammation. 2018. 15(1):172. https://doi.org/10.1186/s12974-018-1210-9.

20. Kim MJ, Im MA, Lee JS, Mun JY, Kim DH, Gu A, et al. Effect of S100A8 and S100A9 on expressions of cytokine and skin barrier protein in human keratinocytes. Mol Med Rep. 2019;20(3):2476-83. https://doi.org/10.3892/ mmr.2019.10454.

21. Huang SJ, Ding ZN, Xiang HX, Fu L, Fei J. Association between serum S100A8/S100A9 heterodimer and pulmonary function in patients with acute exacerbation of chronic obstructive pulmonary disease. Lung. 2020;198(4): 645-52. https://doi.org/10.1007/s00408-020-00376-9.

22. Koh HM, An HJ, Ko GH, Lee JH, Lee JS, Kim DC, et al. Prognostic role of S100A8 and S100A9 protein expressions in non-small cell carcinoma of the lung. J Pathol Transl Med. 2019;53(1):13-22. https://doi.org/10.4132/jptm.201 8.11 .12

23. Hogmalm A, Bry M, Strandvik B, Bry K. IL-1 $\beta$ expression in the distal lung epithelium disrupts lung morphogenesis and epithelial cell differentiation in fetal mice. Am J Physiol Lung Cell Mol Physiol. 2014;306(1):L23-34. https:// doi.org/10.1152/ajplung.00154.2013.

24. González-López A, Aguirre A, López-Alonso I, Amado L, Astudillo A, Fernández-García MS, et al. MMP-8 deficiency increases TLR/RAGE ligands S100A8 and S100A9 and exacerbates lung inflammation during endotoxemia. PLoS One. 2012;7(6):e39940. https://doi.org/10.1371/journal. pone.0039940.

25. Cao B, Huang Y, She DY, Cheng QJ, Fan H, Tian XL, et al. Diagnosis and treatment of community-acquired pneumonia in adults: 2016 clinical 
practice guidelines by the Chinese Thoracic Society, Chinese Medical Association. Clin Respir J. 2018;12(4):1320-60.

26. Fu L, Chen YH, Bo QL, Song YP, Ma L, Wang B, et al. Lipopolysaccharide Downregulates $11 \beta$-Hydroxysteroid dehydrogenase 2 expression through inhibiting peroxisome proliferator-activated receptor- $\gamma$ in placental Trophoblasts. J Immunol. 2019;203(5):1198-207. https://doi.org/10.4049/ jimmunol.1900132.

27. Fu L, Chen YH, Xu S, Yu Z, Zhang ZH, Zhang C, et al. Oral cholecalciferol supplementation alleviates lipopolysaccharide-induced preterm delivery partially through regulating placental steroid hormones and prostaglandins in mice. Int Immunopharmacol. 2019;69:235-44. https://doi.org/10.1016/j. intimp.2019.01.052.

28. Fei J, Fu L, Cao W, Hu B, Zhao H, Li JB. Low vitamin D status is associated with epithelial-Mesenchymal transition in patients with chronic obstructive pulmonary disease. J Immunol. 2019;203(6):1428-35. https://doi.org/10.4049/ jimmunol.1900229.

29. Fei J, Fu L, Hu B, Chen YH, Zhao H, Xu DX, et al. Obeticholic acid alleviate lipopolysaccharide-induced acute lung injury via its anti-inflammatory effects in mice. Int Immunopharmacol. 2019;66:177-84. https://doi.org/10.1 016/j.intimp.2018.11.005.

30. Torres A, Cillóniz C, Ferrer M, Gabarrús A, Polverino E, Villegas S, et al. Bacteraemia and antibiotic-resistant pathogens in community acquired pneumonia: risk and prognosis. Eur Respir J. 2015;45(5):1353-63. https://doi. org/10.1183/09031936.00152514.

31. Huang Y, Liu A, Liang L, Jiang J, Luo H, Deng W, et al. Diagnostic value of blood parameters for community-acquired pneumonia. Int Immunopharmacol. 2018;64:10-5. https://doi.org/10.1016/j.intimp.2018.08. 022.

32. Meyer Sauteur PM, Krautter S, Ambroggio L, Seiler M, Paioni P, Relly C, et al. Improved diagnostics help to identify clinical features and biomarkers that predict Mycoplasma pneumoniae community-acquired pneumonia in children. Clin Infect Dis. 2019:ciz1059. https://doi.org/10.1093/cid/ciz1059.

33. Uhel F, Scicluna BP, van Vught LA, Cremer OL, Bonten MJ, Schultz MJ, et al. Matrix metalloproteinase-8: a useful biomarker to refine the diagnosis of community-acquired pneumonia upon intensive care unit admission? Crit Care. 2019;23(1):226. https://doi.org/10.1186/s13054-019-2513-7.

\section{Publisher's Note}

Springer Nature remains neutral with regard to jurisdictional claims in published maps and institutional affiliations.

Ready to submit your research? Choose BMC and benefit from:

- fast, convenient online submission

- thorough peer review by experienced researchers in your field

- rapid publication on acceptance

- support for research data, including large and complex data types

- gold Open Access which fosters wider collaboration and increased citations

- maximum visibility for your research: over $100 \mathrm{M}$ website views per year

At $\mathrm{BMC}$, research is always in progress.

Learn more biomedcentral.com/submissions 